\title{
Interactive effects of reducing exercise intensity and Adiantum capillus veneris extract on remodeling and modulation of pulmonary apoptotic indices in the rats exposed to the hypoxia.
}

\author{
Yadegari M., PhD ${ }^{1}$, Riahy S., PhD $^{2}$, Mirdar Sh., PhD ${ }^{3}$, Hamidian Gh., PhD $^{4}$ \\ 1. PhD in Exercise Physiology, Department of Exercise Physiology, Faculty of Physical Education and Sport Sciences, \\ University of Mazandaran, Mazandaran, Iran. \\ 2. PhD in Exercise Physiology, Faculty of Aerospace Medicine and subsurface, Army Medical University, Tehran, Iran. \\ 3. Professor, PhD in Exercise Physiology, Department of Exercise Physiology, Faculty of Physical Education and Sport \\ Sciences, University of Mazandaran, Mazandaran, Iran. \\ 4. Assistant Professor, PhD in Comparative Histology, Department of Basic Sciences, Faculty of Veterinary Medicine, \\ University of Tabriz, Tabriz, Iran (Corresponding Author), Tel:+98-41-36378743, hamidian@ tabrizu.ac.ir
}

\begin{abstract}
Background and Aim: Apoptosis is a type of programmed cell death occurring by a series of intercellular messages which is associated with tissue structure remodeling. The purpose of the present study was to investigate the interactive effects of reducing exercise intensity and Adiantum capillus veneris extract on remodeling and modulation of pulmonary apoptotic indices of the rats exposed to the hypoxia.

Material and Methods: This study included 16 male Wistar rats. After 6 weeks of high intensity interval training, the rats were kept in a hypoxic environment for 3 weeks. In hypoxic environment, half of the rats performed interval training and taper and received 500 $\mathrm{mg} / \mathrm{kg}$ of Adiantum capillus veneris extract. Finally, lung tissue was extracted for immunohistochemical and stereology studies.

Results: 3 weeks of simultaneous exercise intensity and taper and Adiantum capillus veneris extract consumption in the hypoxia group led to decreased $\mathrm{Bax} / \mathrm{Bcl}-2$ ratio $(\mathrm{p}<0.05)$ and nematocytes- 2 population ( $p>0.05$ ), compared to increased alveolar nematocytes- 1 population in the hypoxia group $(\mathrm{p}<0.05)$.

Conclusion: The results of this study showed that simultaneous use of exercise intensity and taper and consumption of Adiantum capillus veneris extract is effective in decreasing apoptosis and remodeling of Alveolar epithelial cells after high intensity interval training and exposure to hypoxia.
\end{abstract}

Key Words: Interval exercise training, Hypoxia, Adiantum capillus veneris, Taper.

Received: Sep 23, 2017 Accepted: Apr 11, 2018 


\title{
اثرات تعاملى كاهش شدت تمرين ورزشى و عصاره ير سياوش در تعديل شاخص هاى ريمدلينك و آيويتوز ريوى رت هاى هيبوكسى شده
}

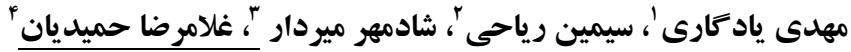

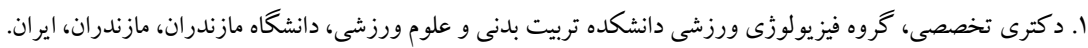

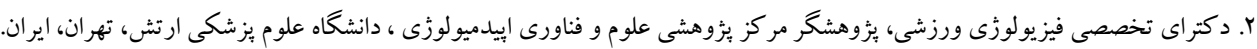

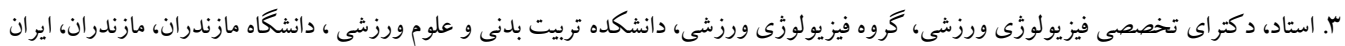

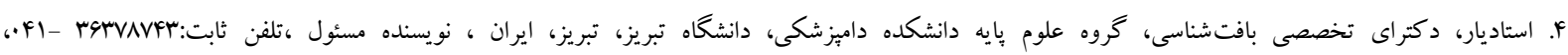

زمينه و هدف: آيويتوز نوعى مر گك برنامه ريزى شده سلول است كه توسط مجموعهاى از بيام هاى بين سلولى رخ مىدهد كه با تغيير ساختارهاى بافتى همراه است. هدف برزوهش حاضر بررسى اثرات تعاملى كاهش شدت تمرين ورزشى و عصاره بر سياوش در تعديل شاخص هاى آيويتوز و ريمدلينك ريوى رت هاى هييو كسى شده بود.

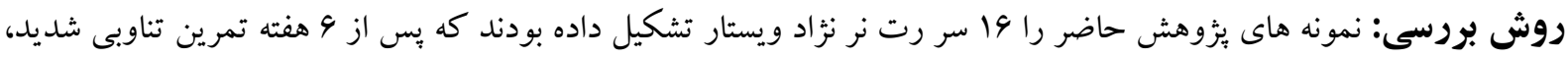

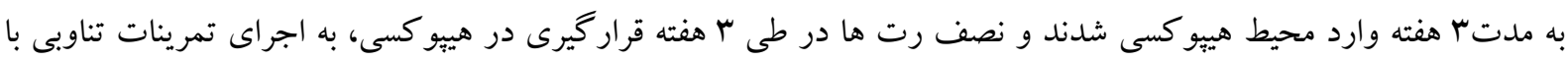

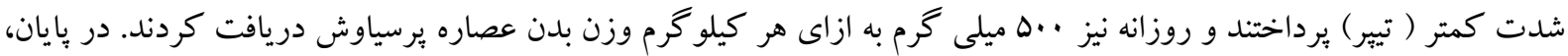

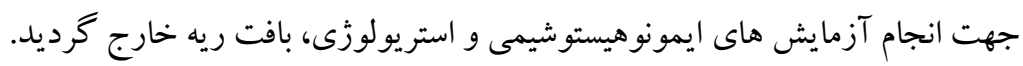

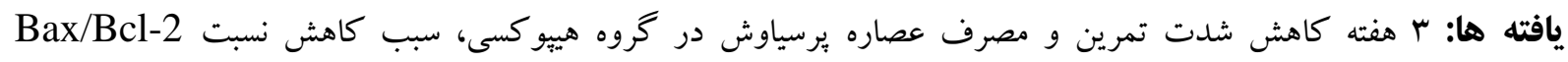

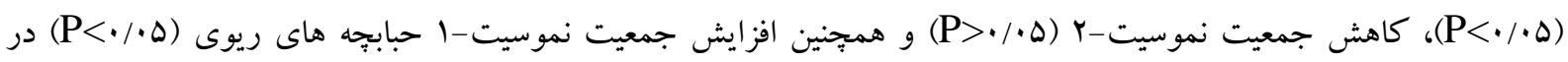
مقايسه با گروه هييو كسى شد. نتيجه كيرى: سودمندى بهره گيرى همزمان از كاهش شدت تمرين و مصرف عصاره يُ سيرسوش در كاهش آيويتوز و ريمدلينك

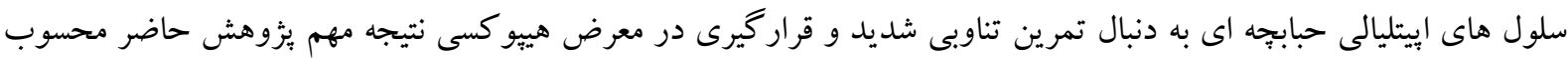
كليد وازه ها: تمرين تناوبى، هييو كسى، ير سياوش، كاهش شدت تمرين وصول مقاله:99/V/I اصلاحيه نهايى:9V/T/9 بذيرش:QV/T/YY 
ميوفيبروبلاست، رسوب ماتريكس خارج سلولى و تغيير

نامتعارف در جمعيت سلول هاى إيتليالى دارد( ·او 9). از جمله عواملى كه مى تواند نقش قوى در تسريع مركّ

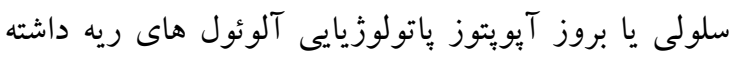

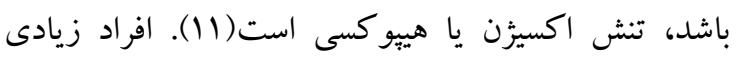
همجيون نيروهاى نظامى و ورزشكاران نخبه، به دلايل مختلف مجبور به اقامت و يا تمرين در محيط هاى مرتفع و ورديه

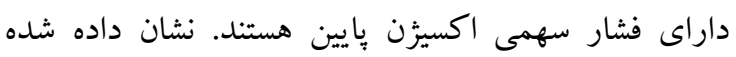

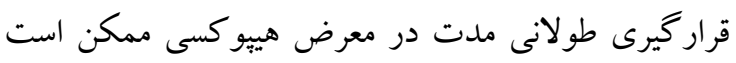

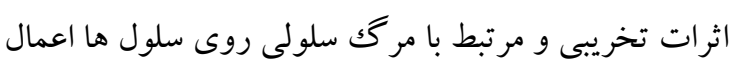

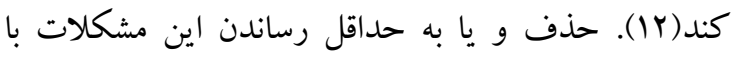

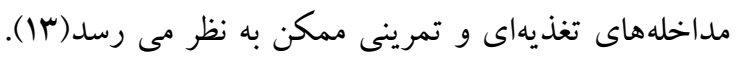

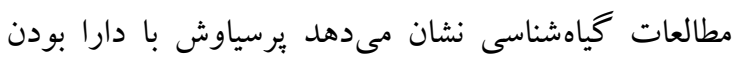

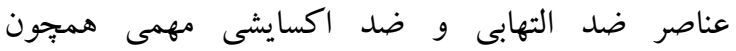

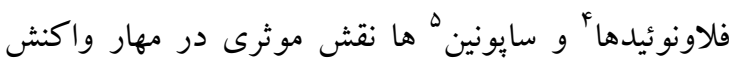
هاى التهابى بازى مى كند و از اين نظر ممكن است دائ در مهار

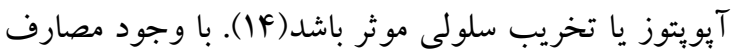

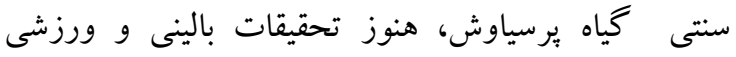

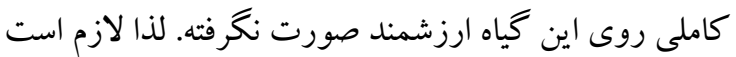

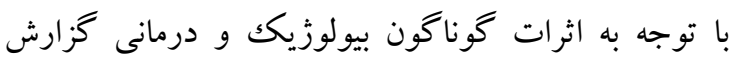

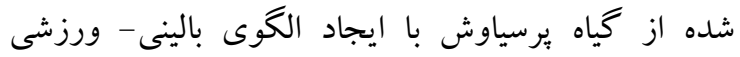
مناسب، از لحاظ بودن در نقش يكك مكمل محافظتى ريه در

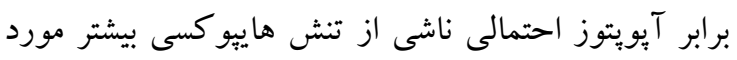

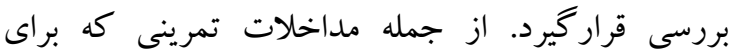
كاهش اثرات منفى ورزش شديد و محيط هييو كسى بيشنهاد

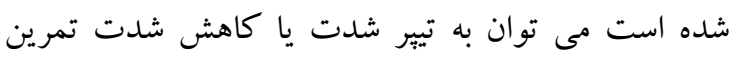

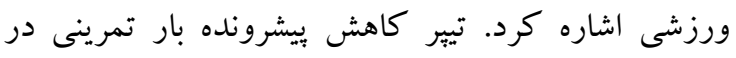

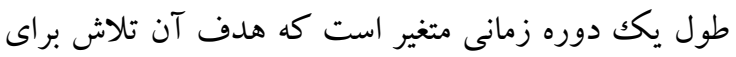
كاهش استرسهاى فيزيولوزيكك و استرسهاى روانى روزانه

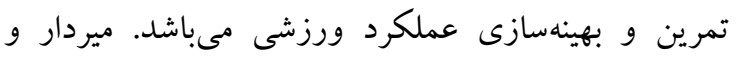

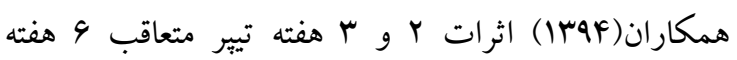

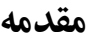

آيويتوز يكك شكل تنظيمى عالى مرك سلول است كه براى نمو طبيعى اندامهاى جندسلولى نياز مى باشد.(r-1).

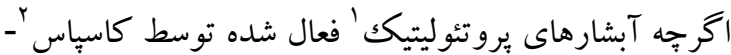
ها نقش محورى را در فر آيند آيويتوز ايفا مى كنند، اما آغاز اين فر آيند توسط عوامل ديخرى تنظيم و كنترل مى شود.

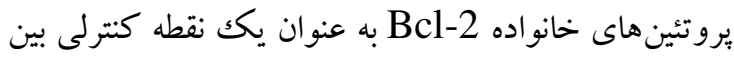
سطح سلول و سيخنال هاى درونى جهت شكل گيرى آيويتوز و فعالسازى آبشار كاسباسى، نقشى حياتى را بر عهلده دارند. بيش از ب إ عضو از اعضاء خانواده Bcl-2 شناسايى شده است كه به دو زير رده اصلى شامل اعضاء ضدآيويتوزى يا مهار كنندها (از قبيل Bcl-2

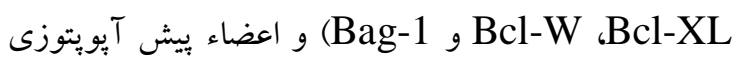

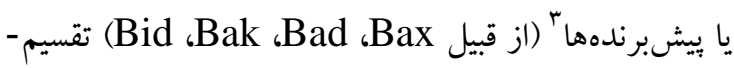

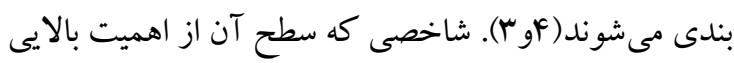

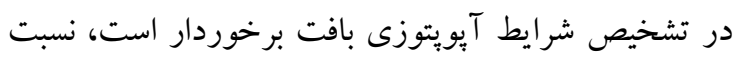
Bax/Bcl-2 آيويتوز و اكر كاهش يابد نشان از كاهش رخداد آيويتوز

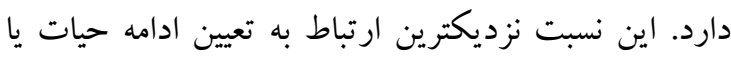

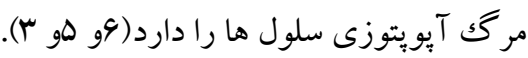
بروز آيويتوز ممكن است با شاخص هاى ساختارى نيز همراه باشد كه از جمله شاخص هاى ساختارى و مورفولوزيكك آن مى توان و به كاهش جمعيت سلولى در بافت هاى مختلف اشاره كرد(N و V). سلول هاى إيتليالى حبابجه هاى ريوى (نموسيت هاى تيّ ا و Y) واحدهايى

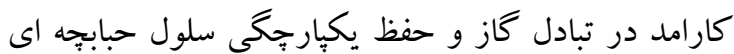
هستند كه تعداد و نسبت آنها نقش موثرى در سلامت يارانشيم ريوى ايفا مى كند. ريمدلينك ريوى اشاره به الكوهاى گسترده بِاتوفيزيولوزيكى از جمله هايبريلازى سلول هاى عضلهى صاف، افزايش فعاليت فيبروبلاست،

\footnotetext{
- Proteolytic

- Caspase

3- Promoters
} 
دستخاه تعبيـه شـده بـود. جهـت جلو گيرى از اثر احتمـالى شو كى الكتريكى بر يافتهاى برزوهش، در مرحله آشناسـازى

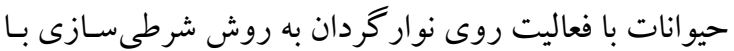

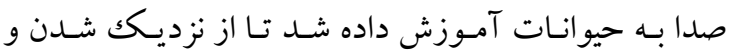
استراحت در بخش انتهايى دستخاه خوددارى كنــد. در طـى

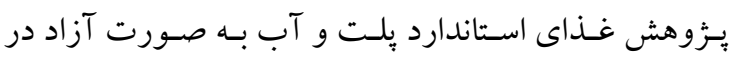

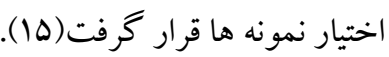
نمونه ها قبل از ورود به محيط هييو كسى بـهـ مـدات 9 هفتـه

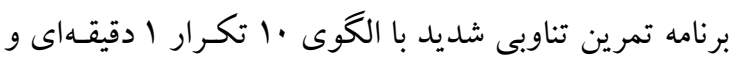

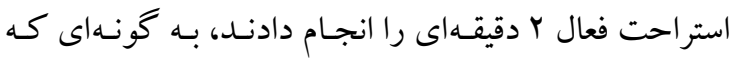
سرعت استراحت نصف سـرعت دويـدن بود وكل تمـرين

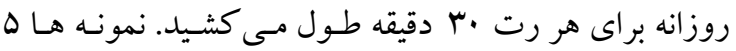
جلسه در هفته تمرين كردند. برنامه تمـرين تنـاوبى شـديد بـا سرعت ها متر بر دقيقه شروع و با سرعت •V متر بر دقيقه در بايان هفته ششم بايان يذيرفت (10). بس از بايان مرحله اول

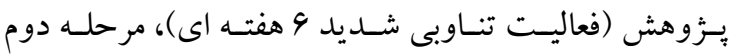
يُزوهش آغاز شد كه r هفته ادامه داشت. در طى اين r هفته نمونه هاى تمرين كرده بـس از 9 هفته تمـرين تناوبى وارد محيط هييو كسى (اتاقك كم فشار \& اكسيزن در محيط شبيه

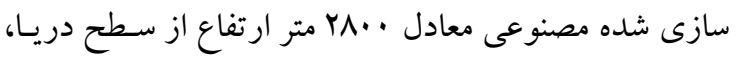

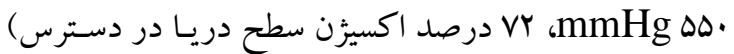
شدند و به مـدت r هفته در آنجـا نكهـدارى شـدند (گُروه هييو كسى). گروه ديخر در طى ب هفته قرار گيـرى در محيط هييو كسى، روزانه تمرين تناوبى خود را بـا همـان الكُوى 9

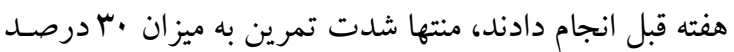

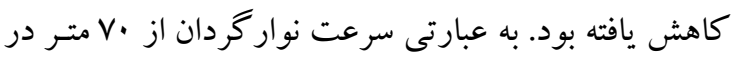

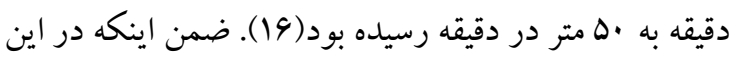
r هفته عصاره يُرسياوش را به صورت كاواز دريافت كردند.

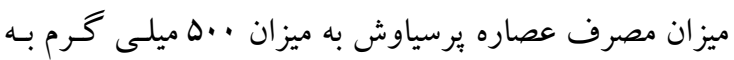

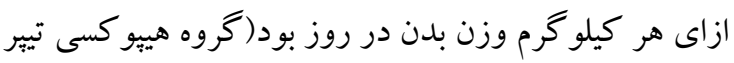

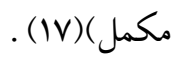

\footnotetext{
1- Hypoxic chamber

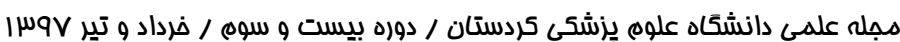

تمرين اينتروال شديد، بر رمدلينك مجارى تنفسى تحتانى رتهاى صحر ايى در حال رشد را بررسى كردند. محققان

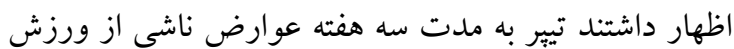
شديد در مجارى تنفسى تحتانى رتها را كاهش مى-

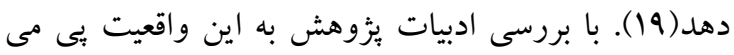

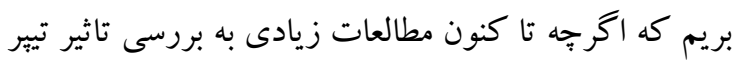

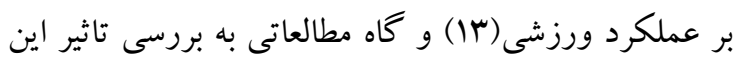

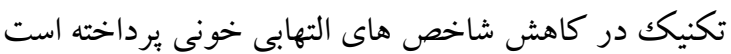

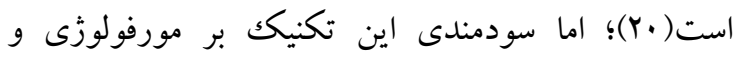
فيزيولوزى بافت، مخصوصا بافت ريه با سوالات بسيارى روبه رو است كه باسخ به آنها مطالعات بيشتر را مى طلبد. با با بال توجه به سوالات بيش رو، بزوهش حاضر بر آن شد تا به بررسى همزمان تيير شدت و عصاره ير سياوش بر نسبت

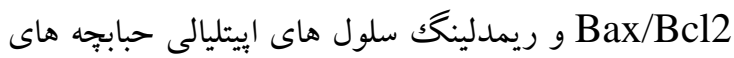

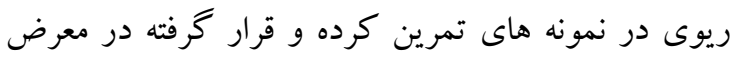

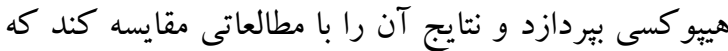
اثرات اين متغيرها را به صورت مجزا بررسى كرده اند.

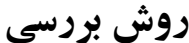

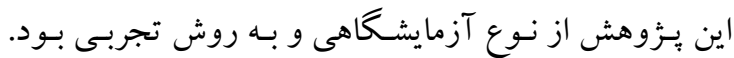
نمونههاى يزوهش حاضر را 19 سر رت نر نزاد ويستار (سـن

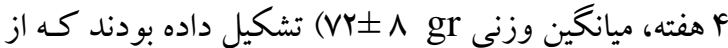
انستيتو باستور شهـهر آمـل خريـدارى شـده و بـه آزمايشـاه جانورى گروه فيزيولوزى ورزشى دانشگاه مازنـدران منتقـل شدند و به صورت تصادفى به گروههاى هييو كسى (1 سر ) و كروه هييو كسى تيير مكمل (N سر ) تقسيم شدند. نمونه هـا از

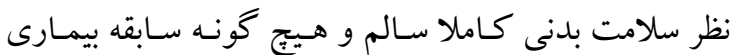

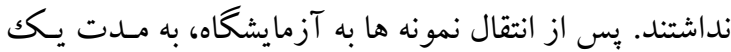
هفته جهت ساز گارى با محيط جديد در دماى بـاسץ درجه

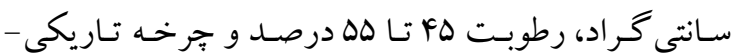

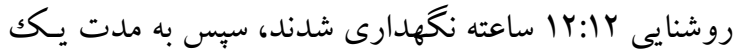

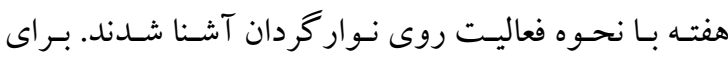

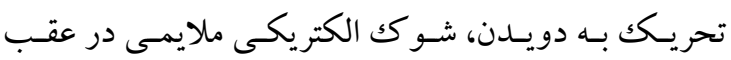


مرحله و به فاصله هـ دقيقه شسته شدند. پِ از آن محلول بِارا فرمالدهيد F درصد به مدت ·r دقيقه به بافت اضافه و در ادامه اسيدكلريدريك نرمال نيز به مدت ·r دقيقه اضافه شد. آنتى بادى اوليه رقيق شده (ا به ..1) با PBS به بافت اضافه گرديد و بعد از ايجاد يك محيط مرطوب براى

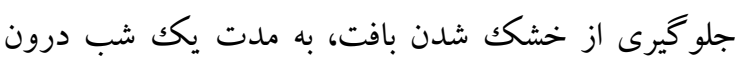
يخجال با دماى Y تا N درجه قرار داده شد. در نهايت به بافت

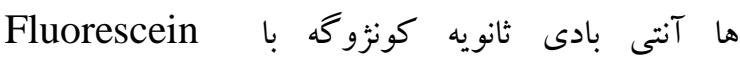
isothiocyanate (FITC)

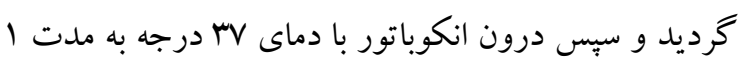

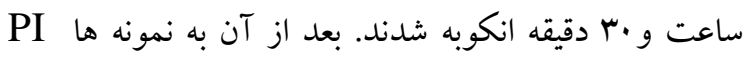

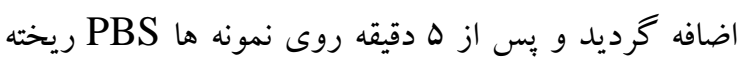

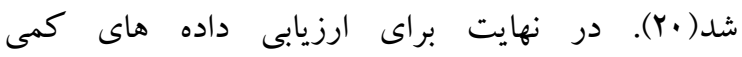

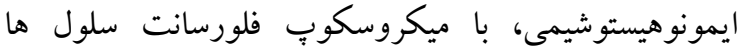

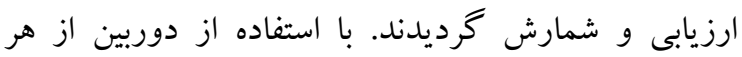
اسلايد ميكروسكوييكك ه فيلد مختلف انتخاب و و

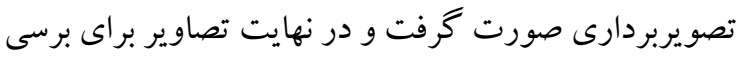
كيفيت واكنش، با نسخه و4/1 نرم افزار ImageJ مور آناليز قرار گر فته و به صورت دادههاى عددى توصيف شدند (Y) (Y). براى تهيه عصاره گياه برسياوش از روش خيساندن استفاده

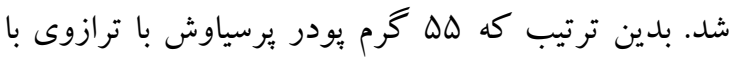
دقت l. درصدآب مقطر به مدت VY ساعت خيسانده شد. در طول اين مدت درب ظرف حاوى خيسانده با پارافين به خوبى يوشانده شد و در دماى محيط • T تا له درجه سانتى گراد نخهارى گرديد. مخلوط هرو ساعت يكبار توسط ميله

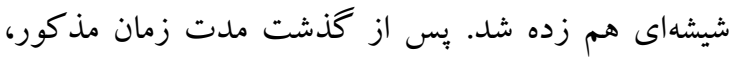

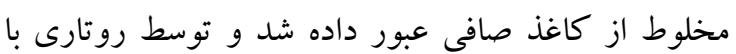

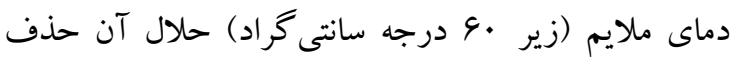
Vرديد. با وزن كردن عصاره غليظ شده بازده آن

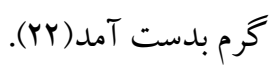

نمونه گيرى بافتى از ريه رت ها \& ساعت بِ از اتمام دوره

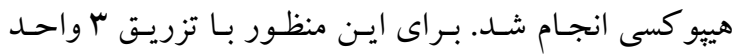

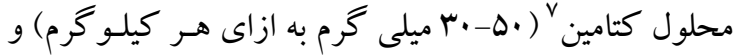

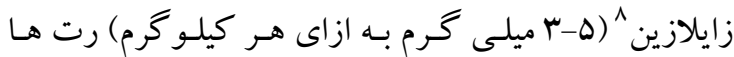

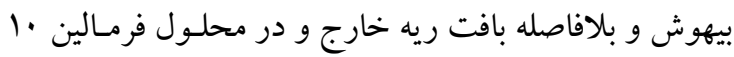
درصد قرار داده شدند. بِس از سهرى شـدن ها روز از زمـان

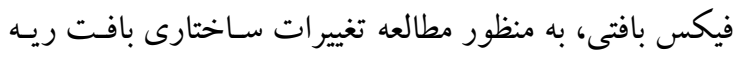
در گروههاى بثزوهش، ابتدا با استفاده از تكنيك اورينتيتور و

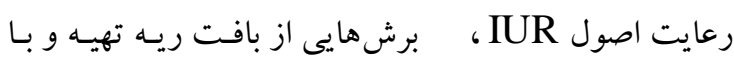

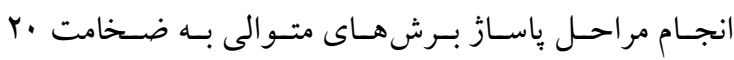

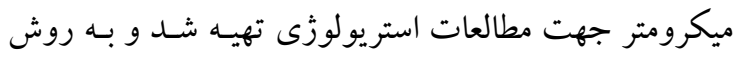
استاندار و معمول با رنكك هماتو كسيلين -ائسوزين (H\&E)

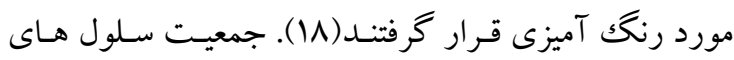

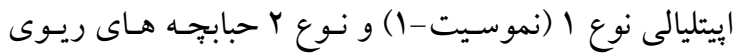

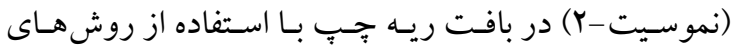

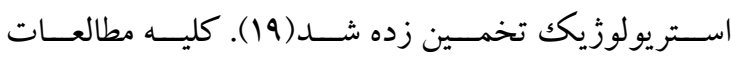
استريولوزيكك با روش اويتيكال فراكشـنيتور و بـا استفاده از ميكروسكوٍ متصل به ميكرواريتور، دوربين و سيستم تمـام Stereo- investigator ديجيتال و نسخه شماره 9 نرم افنز انجام شد. از هر ريه به طور تصادفى بنج برش نازك غير متوالى به ضخامت ه ميكرومتر جهت بررسى ايمونوهيستوشيميايى بيان

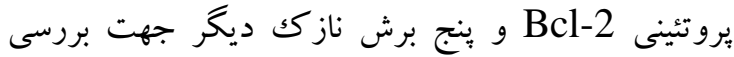
ايمونوهيستوشيميايى بيان يروتئينى Bax انتخاب شدند.

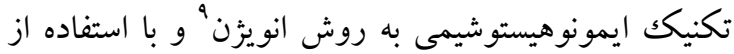

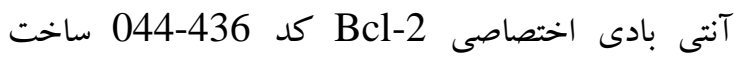
شركت Bax و Malli pore كد 69643 ساخت شركت Abcam

جهت مطالعات ايمونوهيستوشيمى در ابتدا محيط كشت

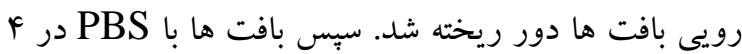


Bax/Bcl-2 حبابجه هاى ريوى را به طور معنادار كاهش

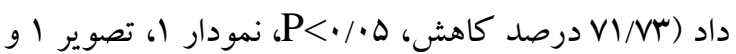
r). همجنين ديده شد r هفته اجراى تكنيك تيِر شدت و مصرف عصاره برسياوش در محيط هييو كسى سبب افزايش معنادار جمعيت نموسيت-1 حبابجه هاى ريوى شد(Nه

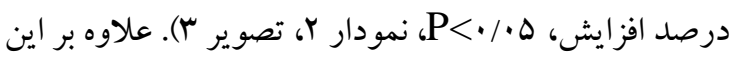

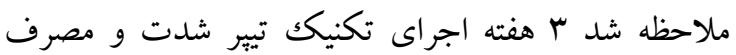

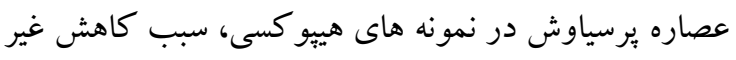

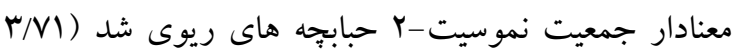

$$
\text { درصد كاهش، نمودار س، تصوير r). }
$$

براى تجزيه و تحليل يافتههاى يـزوهش از روش هـاى آمـار

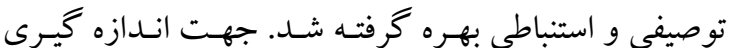
ميانگين و انحراف استاندارد گحروه هـا از آمـار توصيفى و جهت ارزيابى طبيعى بودن توزيع داده هـا از آزمـون آمـارى كلومو گروف اسميرنوف (k-s) استفاده شد. از آزمون آمار استنباطى t مستقل نيز جهت مقايسه ميانخين گروه ها استفاده

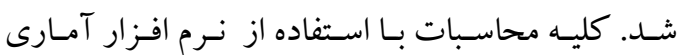
SPSS.21 ور سطح معنادارى ه • • P انجام شد.

\section{يافته ها}

تحليل آمارى نشان داد ب هفته اجراى تكنيك تيبر شدت و

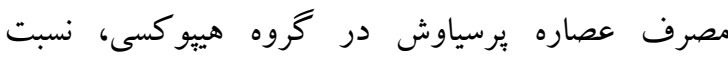

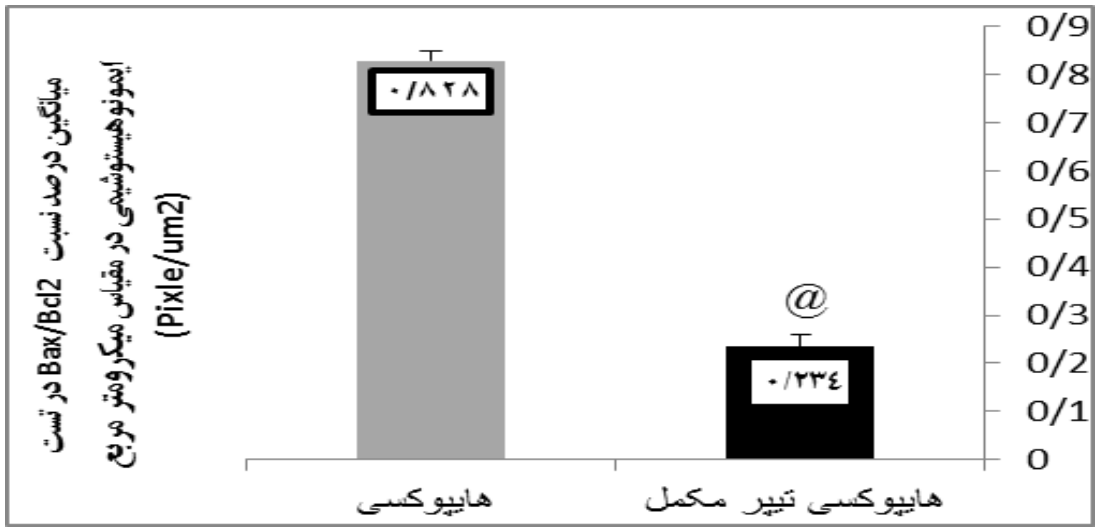

نمودار ا. ميانگين و خطاى استاندارد نسبت Bax/Bcl2 حبابجه ريوى در گروه هاى يُزوهش. داده ها بر حسب ميانگين ذخطاى

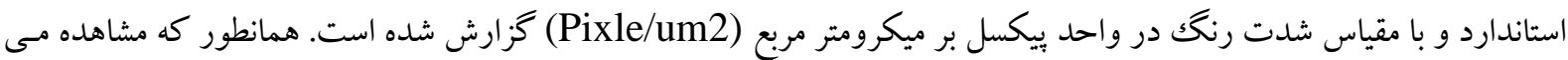

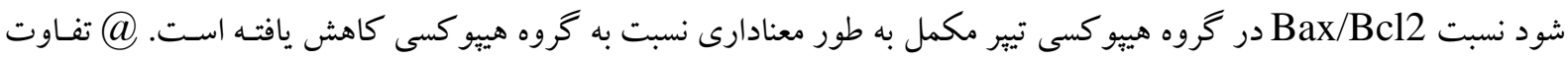

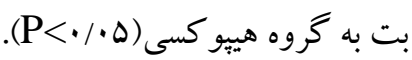



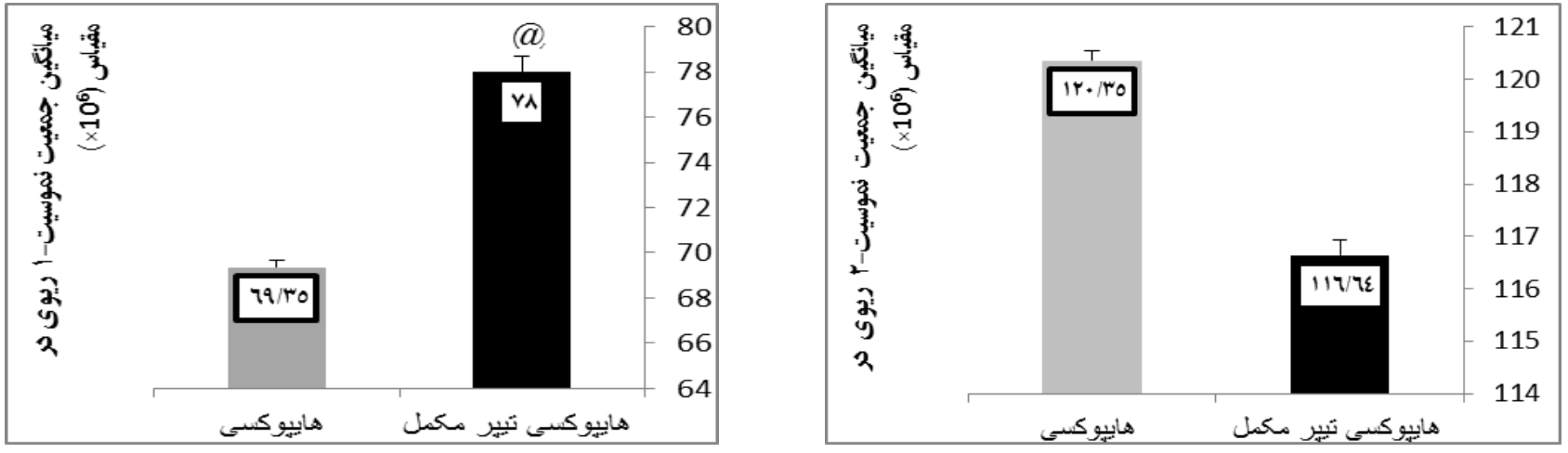

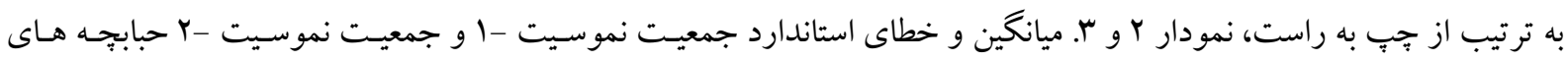

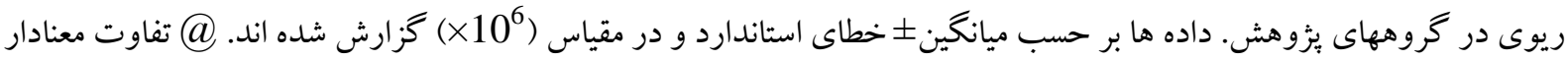

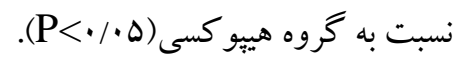

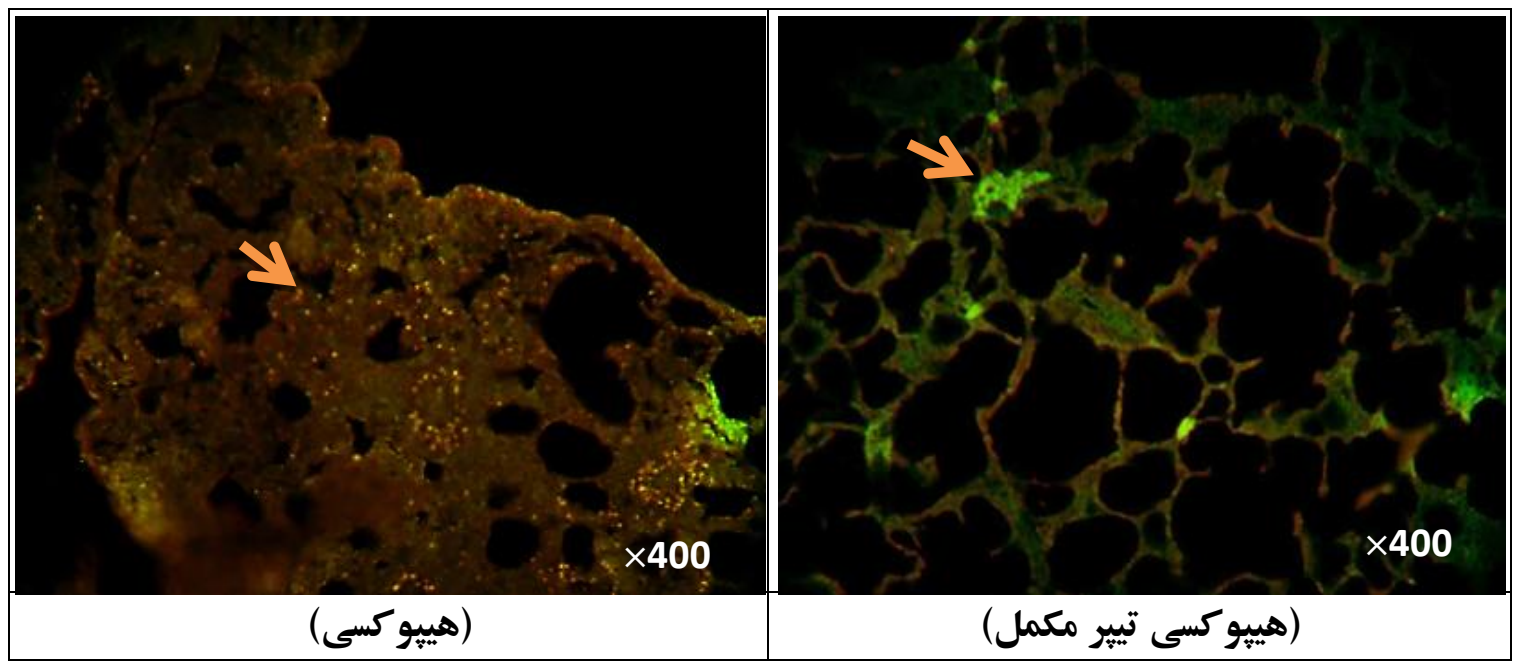

تصوير ا. تصاور مربوط به بررسى ايمونوهيستوشيميايى شاخص بروتئينى Bax در گروه هاى بثزوهش. آنتى بادى ثانويه Bax به رنكى FITC متصل شده

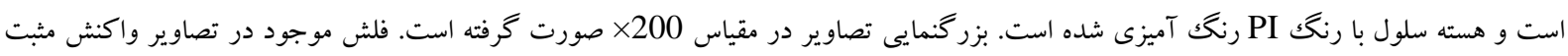

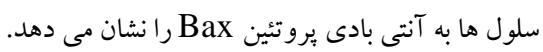




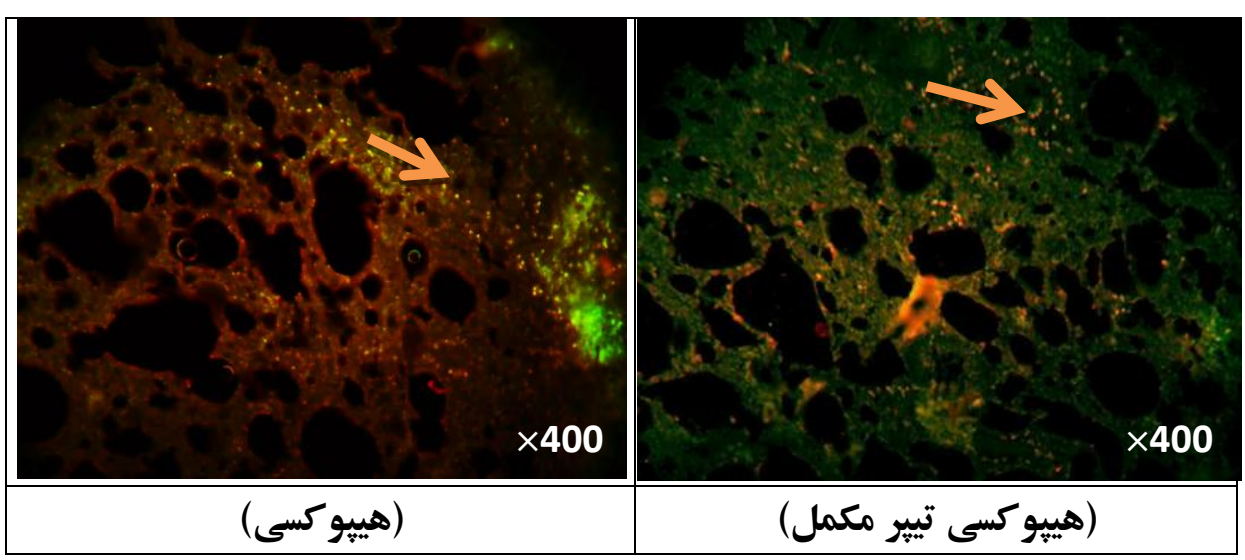

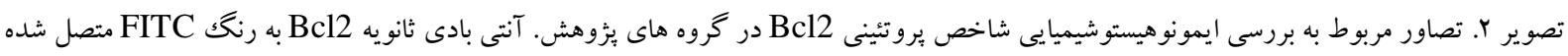

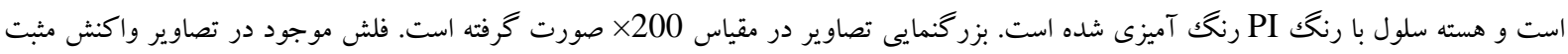

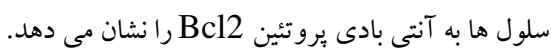

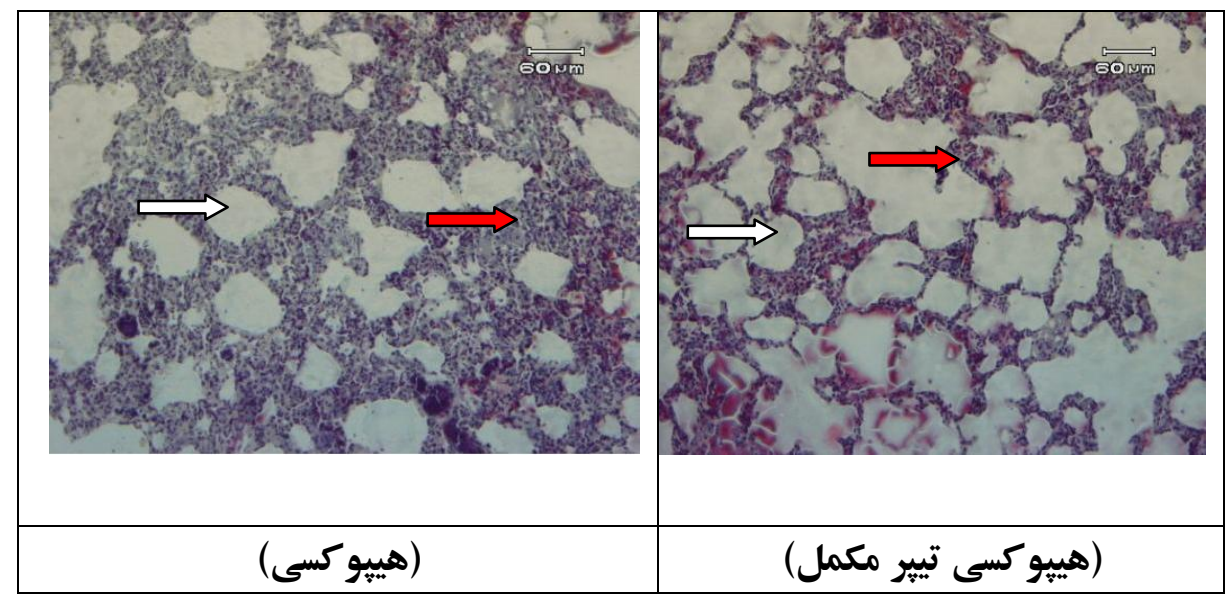

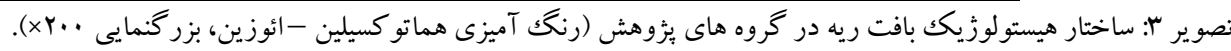

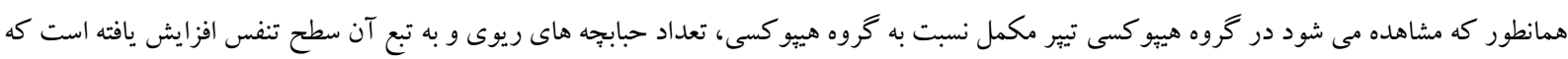

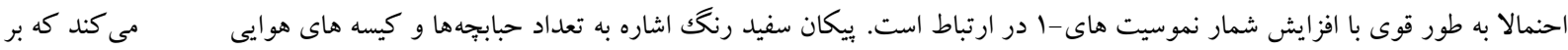

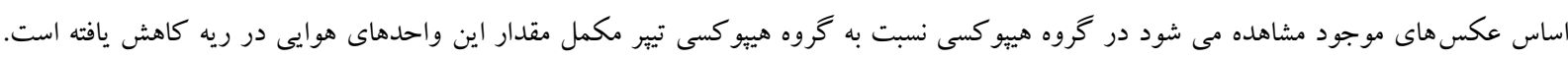

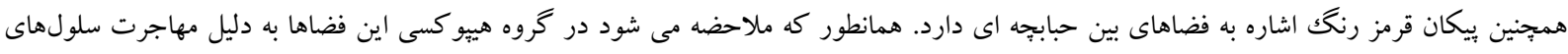

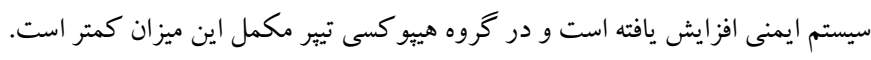

تكنيك تيبر شدت و مصرف عصاره يرسياوش در محيط

بحث

هييو كسى سبب افزايش معنادار جمعيت نموسيت-1 حبابجه نتايج مطالعه ما نشان داد ب هفته اجراى تكنيك تيبر شدت و هاى ريوى گر ديد. مصرف عصاره يرسياوش در گروه هييو كسى، نسبت با توجه به يافته ها، به نظر مى رسد نمونه هاى تمرين كرده و حبابجه هاى ريوى را به طور معنادار كاهش قرار گرفته در معرض هيبوكسى، سطوحى از بيشرفت مى دهد. اين كاهش به صورت غيرمعنادار نيز در جمعيت آيويتوز را تجربه كرده اند كه با تغييرات ساختارى در نموسيت-Y ديده شد. همجنين مشاهده شد r هفته اجراى 
هييو كسى اين تغييرات را به نحو كار آمدى تعديل كرده و به سطوح استراحتى نزديكك مى كند. در اين مطالعه ميزان كاهش شاخص بيش آيويتوزى Bax/Bcl2 با اجراى

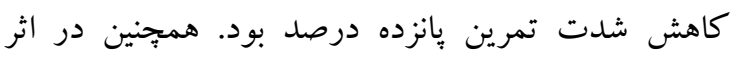

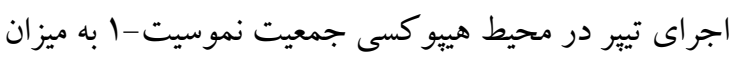

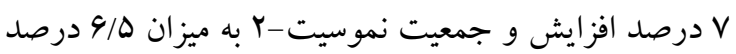

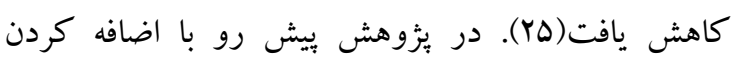

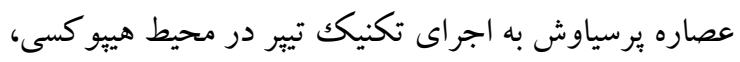

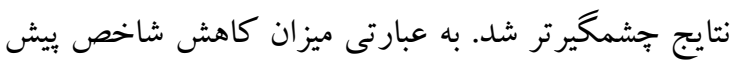
آيويتوزى Bax/Bcl2 نموسيت-1 حدود 9 درصد بود كه نشان از تاثير تعاملى مفيد كاهش شدت تمرين و عصاره برسياوش در بهبود شاخص آيويتوزى و ريمدلينك حبابجه هاى ريوى دارد.

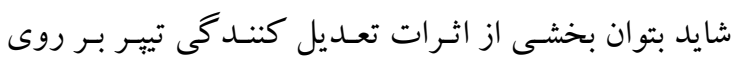

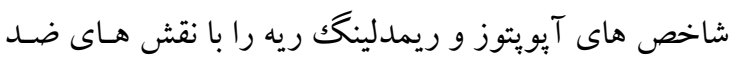
اكسايشى و ضـــ التهابى تيــر توجيـه كـرد. در ايـن راسـتا

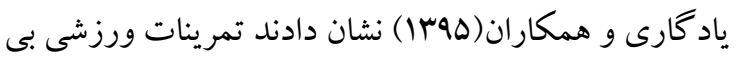
هوازى و شديد قادر هستند بارانشيم ريه را به سمت التهاب و

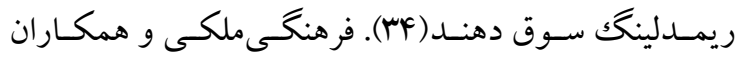

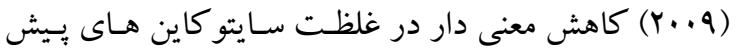
التهابى TNF-a و IL-6 ، IL-1B بـس از يـك دوره تيّر

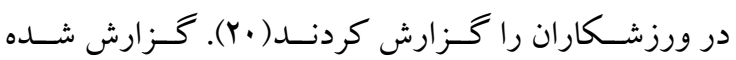
سايتو كين هاى بيش التهابى از جمله عواملى هستند كه منجر

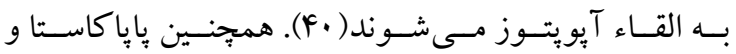

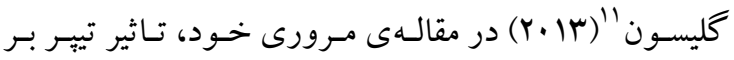
عملكرد سيستم ايمنى را بررسى كردند. آنها تيير را به عنوان

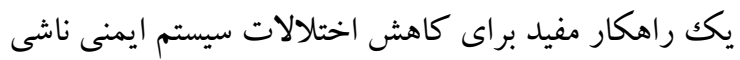

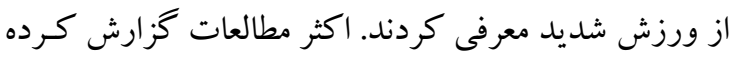

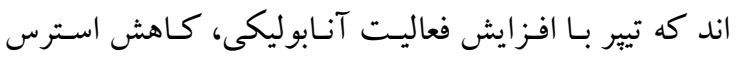

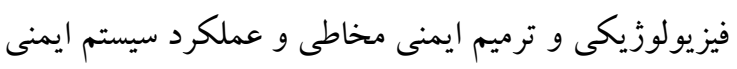

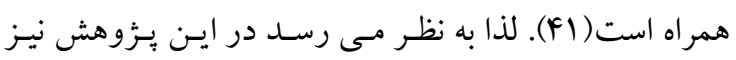

حبابجه هاى ريوى همراه بوده است. در ادامه جِنين بر مى آيد كه كاهش شدت تمرين و بهره گيرى از عصاره گياهى يرسياوش تا حدود بسيار زيادى توانسته است مهمترين

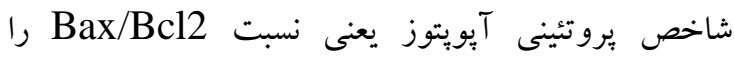

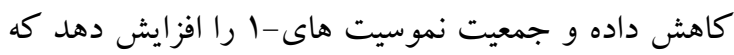
نقش مهمى در ساختار ديواره حبابجه اى و توسعه سطح

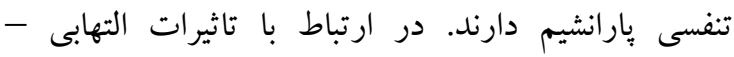

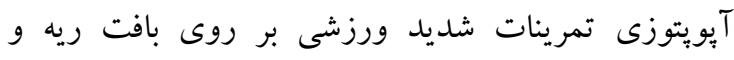

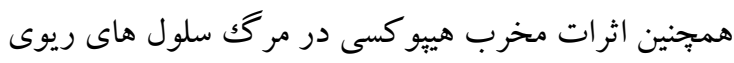

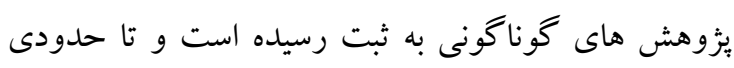

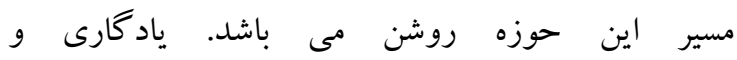

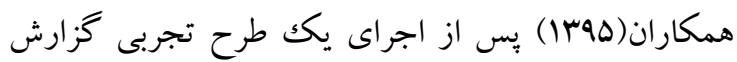

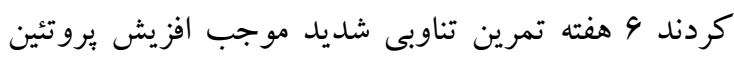
بيش آبويتوزى Bax و تا حدودى Bcl2 مى شى شود. نتايج

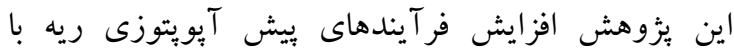

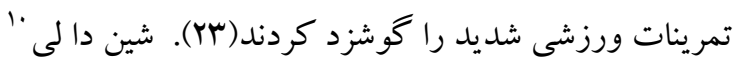

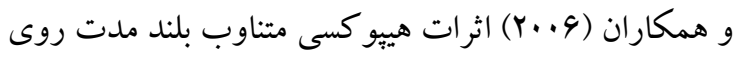

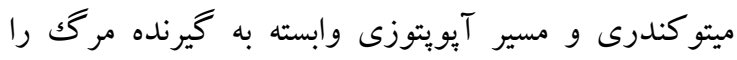
بررسى كردند. نتايج نشان داد فعاليت مسير آيويتوزى وابسته

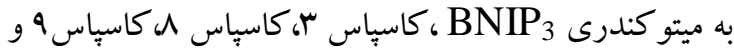

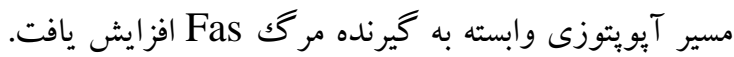

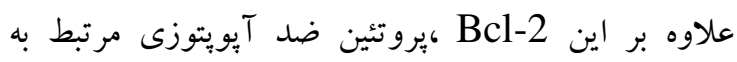

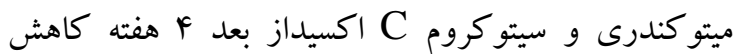
يافت(YF). در همين راستا يادكارى و همكاران (צوسا) در يكك طرح تجربى بر روى نمونه هاى رت باليده شده به اين نتيجه رسيدند كه يكك دوره تمرينات ورزشى شدئ دونه،

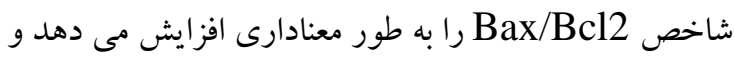
در كنار شاخص آيويتوزى، ريمدلينگك معيوب در نموسيت هاى حبابجه اي را موجب مى شود. اين محققان همجِين

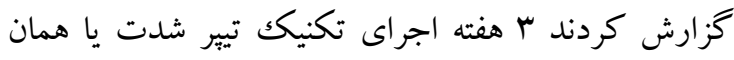
كاهش شدت تمرين ورزشى و ادامه آن در شرايط

10 - Shin-Da lee 


\section{نتيجه كيرى}

فوايد بيشتر بهره كيرى همزمـان از كـاهش شـدت تمـرين و مصرف برسياوش در كاهش آبويتوز و ريمـدلينگك اييتليـالى حبابجه هاى ريوى به دنبال تمرين تناوبى شديد و قرارگيرى در معرض هيبيو كسى نتيجـه مهـم يـرزوهش حاضـر محسـوب مىشود. همجينين با توجه به مقايسه يافته هاى اين ثئوهش بـا يزؤهش هاى مشابه كذشته، به نظر مى رسد جهت حمايت از فراينــهاى رشـــ سـلولى در حبابجـهـ هـاى ريسوى و مهـار فرايندهاى يسيش آيويتوزى ناشىى از قرار گيـرى در معـرض هيبو كسى، استفاده همزمان از تكنيك تيـر شـدت و و عصـاره يرسياوش موثرتر از استفاده هر كدام به تنهايى است.

\section{تشكر و قدردانى}

مطالعه حاضر بركرفته از طرح يثوهشى مورد نياز ستاد كـل

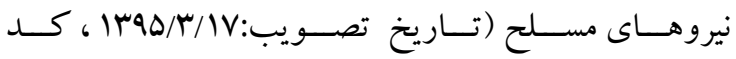

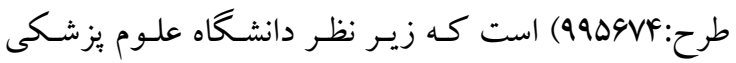
ارتش (آجا) و با حمايست مـالى آن و همبجنـين بـا مسـاعدت دانشگاه هاى مازندران و تبريز به سر انجام رسيد. بدين وسيله از مساعدت اساتيد و كارشناسان محترم مراكز نام برده تشكر و قدردانى بعمل مى آيد.
احتمالا تيبر توانسته اسـت اختلالات سيستم ايمنسى در بيـان فاكتورهاى بيش التهابى مختلف را متعادل كند و احتمـالا بـا مهار بيان بيش از حد آنها در شرايط تمرين و هييو كسىى، بـه

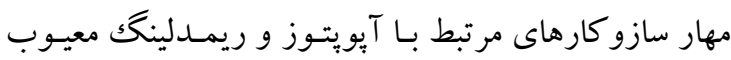

اييتليالى كمك كند(Fr). (F).

از سـويى ارزيـابى فيتوشـيميايى برسـياوش نشـان از حضـور

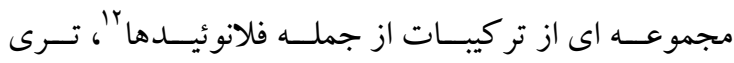

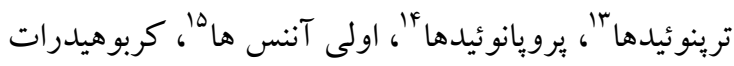

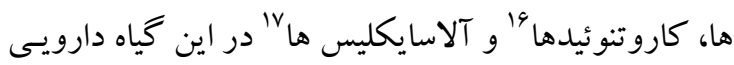

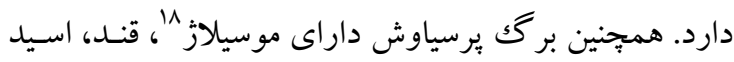

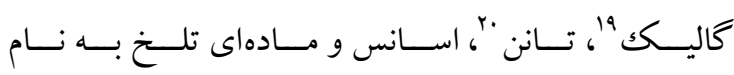
كاييلارين "است. بسيارى از تركيبات ياد شده توانايى خنثى سازى راديكال هاى آزاد و كاهش التهاب را دار هسـتند. در اين راستا گَزارش شـد عصـاره يرسـياوش توانـايى مهـار يـر اكسيداسيون جربى و افزايش فعاليت آنتى اكسيدانى آنزيم هـا و همجنــين افـزايش محتـواى كلوتـاتيونى تسام راد دارد. يكى از سـايتو كاين هـاى قـوى در بـروز آيويتـوز

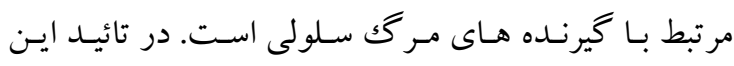
فرضيات، مشاهده شد عصـاره برسـياوش توانـايى مهار بيـان TNF- $\alpha$ شده كه بخش مهمى از اين تاثيرات مهارى ناشى از غير فعال

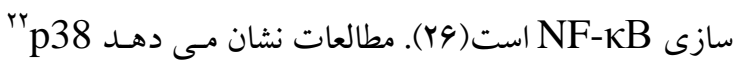

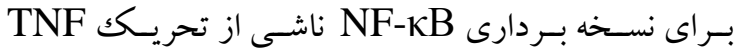
ضرورى است. عنوان شده است كه عصاره برسياوش ممكن است به طور انتخـابى بـر فسفريلاسـيون p38 MAPK اثر

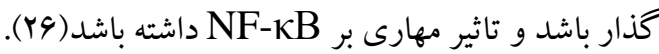

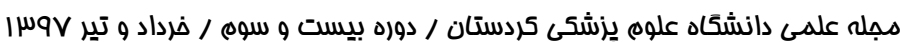

12 - flavonoids
13 - triterpenoids
14 - phenylpropanoids
15 - oleananes
16 - carotenoids
17 - alicyclics
18 - Mucilage
19 - Gallic acid
20 - tannin
21 - Capillarine
22 - mitogen-activated protein kinases 


\section{Reference}

1. Phaneuf S, Leeuwenburgh C. Apoptosis and exercise. Med Sci Sports Exerc 2001; 33: 3936.

2. Krakstad C, Chekenya M. Survival signalling and apoptosis resistance in glioblastomas: opportunities for targeted therapeutics. Mol Cancer 2010; 9: 135.

3. Youle RJ, Strasser A. The BCL-2 protein family: opposing activities that mediate cell death. Nat Rev Mol Cell Biol 2008; 9: 47-59.

4. Kroemer G, Galluzzi L, Brenner C. Mitochondrial membrane permeabilization in cell death. Physiol Rev 2007; 87: 99-163.

5. Quadrilatero J, Alway SE, Dupont-Versteegden EE. Skeletal muscle apoptotic response to physical activity: potential mechanisms for protection. Appl Physiol Nutr Metab 2011; 36: 608-17.

6. Krüger K, Mooren FC. Exercise-induced leukocyte apoptosis. Exerc Immunol Rev 2014; 20: $117-34$

7. Ranjbar K, Nazem F, Nazari A, Golami MR. Effect of 10 weeks aerobic exercise training on left ventricular systolic function, Caspase-3 level and infarction size in myocardial infarction rat. Knowledge Health, J Shahroud Univ Med Sci 2015; 10: 20-9. [In Persian]

8. Ghibelli L, Fanelli C, Rotilio G, Lafavia E, Coppola S, Colussi C, et al. Rescue of cells from apoptosis by inhibition of active GSH extrusion. FASEB J 1998; 12: 479-86.

9. Westergren-Thorsson G, Larsen K, Nihlberg K, Andersson-Sjöland A, Hallgren O, Marko-Varga G, et al. Pathological airway remodelling in inflammation. Clin Respir J 2010; 4: $1-8$.

10. Fehrenbach H. Alveolar epithelial type II cell: defender of the alveolus revisited. Respir Res 2001; 2: 33-46.

11. Shimoda LA, Semenza GL. HIF and the lung: role of hypoxia-inducible factors in pulmonary development and disease. Am J Respir Crit Care Med 2011; 183: 152-6.

12. Jain M, Sznajder JI. Effects of hypoxia on the alveolar epithelium. Proc Am Thorac Soc 2005; 2: 202-5.

13. Mujika I. Intense training: the key to optimal performance before and during the taper. Scand J Med Sci Sports 2010; 20: 24-31.

14. Yuan Q, Zhang X, Liu Z, Song S, Xue P, Wang J, et al. Ethanol extract of Adiantum capillus-veneris L. suppresses the production of inflammatory mediators by inhibiting NF- $\mathrm{KB}$ activation. J Ethnopharmacol 2013; 147: 603-11.

15. Yadegari M, Mirdar S, Hamidian Gh. The effect of high-intensity interval training on lung parenchymal and non-parenchymal structural changes. Daneshvar Med 2016; 23: 51-60. [In Persian]

16. Mirdar S, Arabzadeh E, Hamidian Gh. Effects of two and three weeks of tapering on lower respiratory tract in the maturing rat. Koomesh 2015; 16: 366-75. [In Persian]

17. Nilforoushzadeh MA, Javanmard SH, Ghanadian M, Asghari G, Jaffary F, Yakhdani AF, et al. The effects of Adiantum capillus-veneris on wound healing: An experimental in vitro evaluation. Int J Prev Med 2014; 5: 1261-8.

18. Schneider JP, Ochs M. Stereology of the lung. Methods Cell Biol 2013; 113: 257-94.

19. Ochs M, Mühlfeld C. Quantitative microscopy of the lung: a problem-based approach. Part 1: basic principles of lung stereology. Am J Physiol Lung Cell Mol Physiol 2013; 305: L15-22.

20. Hofman F. Immunohistochemistry. Curr Protoc Immunol 2002; 21: 21-4. 
21. Di Cataldo S, Ficarra E, Acquaviva A, Macii E. Automated segmentation of tissue images for computerized IHC analysis. Comput Methods Programs Biomed 2010; 100: 1-15.

22. Wendakoon C, Calderon P, Gagnon D. Evaluation of selected medicinal plants extracted in different ethanol concentrations for antibacterial activity against human pathogens. $\mathrm{J}$ Med Act Plants 2012; 1: 60-8.

23. Yadegari M, Riahi S, Mirdar S, Hamidian Gh, Yousefpour M. Riyahi F. Immunohistochemical detection of apoptotic factors Bax and Bcl-2 in the lung alveoli, followed by six weeks of high intensity exercise training. Daneshvar Med 2016; 24: 31-40. [In Persian]

24. Lee SD, Kuo WW, Lin JA, Chu YF, Wang CK, Yeh YL, et al. Effects of long-term intermittent hypoxia on mitochondrial and Fas death receptor dependent apoptotic pathways in rat hearts. Int J Cardiol 2007; 116: 348-56.

25. Yadegari M, Mirdar S, Hamidian Gh, editors. The impact of three weeks taper in hypoxic environment on apoptotic index of $\mathrm{Bax} / \mathrm{Bcl} 2$ and pulmonary alveolar epithelial cell population. Proceedings of 10th International Congress on Sport Science. 2017 April. 26-27, Tehran, Iran.

26. Yuan Q, Zhang X, Liu Z, Song S, Xue P, Wang J, et al. Ethanol extract of Adiantum capillus-veneris L. suppresses the production of inflammatory mediators by inhibiting NF- $\kappa \mathrm{B}$ activation. J Ethnopharmacol 2013; 147: 603-11. 